\title{
Characterization of the Renibacterium salmoninarum haemagglutinin
}

\author{
James G. Daly $\dagger$ and Roselynn M. W. STEVEnSON* \\ Department of Microbiology, College of Biological Sciences, University of Guelph, Guelph, Ontario, Canada N1G 2WI
}

(Received 21 August 1989; revised 5 January 1990; accepted 2 February 1990)

\begin{abstract}
Water-extracted proteins from nine geographically diverse strains of Renibacterium salmoninarum, all of which agglutinated rabbit erythrocytes and rainbow trout spermatozoa, were compared by SDS-PAGE. Extracts from eight strains, including the type strain, ATCC 33209, were similar, containing a major protein of $57 \mathrm{kDa}$ and a minor protein of $58 \mathrm{kDa}$. The SDS-PAGE protein profile of the Char strain did not contain the $58 \mathrm{kDa}$ protein. A non-agglutinating strain, MT-239, which was also non-hydrophobic, did not produce any water-extractable protein. Immunoblot reactions with rabbit antiserum prepared against whole cells of the type strain demonstrated that the water-extracted haemagglutinins from the various strains were antigenically related. When purified by polyacrylamide gel zone electrophoresis, the haemagglutinin from $R$. salmoninarum ATCC 33209 formed a doublet band with molecular masses of 57 and $58 \mathrm{kDa}$, similar to the previously described $\mathrm{F}$ antigen. The waterextracted haemagglutinin agglutinated salmonid spermatozoa, was degraded by protease $K$ and trypsin, and was shown to self-assemble onto the cell surface.
\end{abstract}

\section{Introduction}

Renibacterium salmoninarum is the Gram-positive bacterium that causes bacterial kidney disease of salmonid fish (Sanders \& Fryer, 1980). It grows very slowly on artificial media, requiring up to $10 \mathrm{~d}$ to grow from heavy inocula and 4-6 weeks from dilute inocula (Fryer \& Sanders, 1981). Thus, serological methods are preferred over culture for its detection. Serological techniques are based on the detection of a heat-stable surface antigen (Pascho \& Mulcahy, 1987) of unknown function. Getchell et al. (1985) described and partially purified the cell-surface and heat-stable $F$ antigen, believed to be the antigen detected in various serological reactions. In this study, we report that antigen $F$ is responsible for the haemagglutinating (Daly \& Stevenson, 1987) and spermagglutinating (Daly \& Stevenson, 1989) properties of $R$. salmoninarum.

\section{Methods}

Bacterial strains and growth. The following strains of $R$. salmoninarum have been previously described (Daly \& Stevenson, 1987): ATCC 33209 (the type strain), ATCC 33739, NCMB 1111,

$†$ Present address: Department of Experimental Animal Morphology and Cell Biology, Agricultural University, PO Box 338, $6700 \mathrm{AH}$ Wageningen, The Netherlands.

Abbreviation: SAT, salt aggregation test (for hydrophobicity).
NCMB 1114, Char, Coho (Ontario), RS22, MT241 and 2/2/79. $R$. salmoninarum MT239 was kindly supplied by Dr D. Bruno, Department of Agriculture and Fisheries for Scotland, Aberdeen, UK. The bacteria were grown biphasically for $10 \mathrm{~d}$ to 2 weeks on charcoal agar (KDM-C) slants at $15^{\circ} \mathrm{C}$, until dense growth was present in the liquid phase (Daly \& Stevenson, 1985).

Haemagglutinin extraction. After 2 weeks of growth, the bacteria were removed from the biphasic agar slants and washed three times with saline $(0.85 \%, \mathrm{w} / \mathrm{v}, \mathrm{NaCl})$. The haemagglutinin was removed from the bacterial surface with two washes of distilled water, $\mathrm{pH} 5 \cdot 5$. This $\mathrm{pH}$ was found to result in high yields of the haemagglutinin. This water-extract was filtered through a $0.45 \mu \mathrm{m}$ membrane (Millipore) and then lyophilized.

Haemagglutinin purification. The lyophilized water-extracted haemagglutinin was rehydrated at $2 \mathrm{mg} \mathrm{ml}^{-1}$ with $2 \mathrm{~mm}$-sodium phosphate buffer, $\mathrm{pH} 6.8$, and mixed with an equal volume of $20 \%(\mathrm{v} / \mathrm{v})$ glycerol and bromophenol blue. The mixture was applied to a $15 \mathrm{~cm}$ vertical polyacrylamide gel for zone electrophoresis, using a $3 \%(\mathrm{w} / \mathrm{v})$ stacking gel and a $5 \%(\mathrm{w} / \mathrm{v})$ separating gel, in $0.05 \mathrm{M}$-Tris $/ 0.38 \mathrm{M}$-glycine buffer, $\mathrm{pH} 8 \cdot 3$. The sample was electrophoresed at $60 \mathrm{~V}$ through the stacking gel and at $120 \mathrm{~V}$ through the separating gel until the tracking dye ran off the bottom of the gel. Vertical strips from each side of the gel were stained with Coomassie brilliant blue R250 to locate a single band which was then excised from the gel. This gel strip was placed in a dialysis sac with a molecular mass cut-off of $6000-8000 \mathrm{Da}$ and $5 \mathrm{ml}$ of distilled water was added. The contents of the sac were then dialysed against two changes of 2 litres of distilled water at $4{ }^{\circ} \mathrm{C}$ for $24 \mathrm{~h}$. The liquid from the dialysis sac was removed and lyophilized; the lyophilized material was rehydrated with saline and assayed for haemagglutinating and spermagglutinating activity.

Agglutination and hydrophobicity assays. Haemagglutination was assayed with $3 \%(\mathrm{v} / \mathrm{v})$ rabbit erythrocytes in saline, on a glass slide, as previously described (Daly \& Stevenson, 1987). For agglutination of 
spermatozoa, cells of $R$. salmoninarum were washed three times in saline and resuspended in saline such that a 50 -fold dilution gave an $\mathrm{OD}_{520}$ of $0 \cdot 10$. Spermatozoa from three mature, spawning rainbow trout (Salmo gairdneri) were pooled and, before use, were diluted in saline until the optical density approximated that of the bacteria. Equal volumes of bacteria and spermatozoa were allowed to react on a glass slide and observed for agglutination as previously described (Daly \& Stevenson, 1989). Hydrophobicity of strains was examined using the salt aggregation test (SAT) as previously described (Daly \& Stevenson, 1987).

Rabbit antiserum production. $R$. salmoninarum ATCC 33209 was grown biphasically on charcoal agar for 2 weeks at $15^{\circ} \mathrm{C}$. The cells were collected from the aqueous phase, washed three times in saline, then resuspended in saline to an $\mathrm{OD}_{600}$ of 0.55 . This suspension was mixed $1: 1$ with incomplete Freund's adjuvant (Calbiochem). A New Zealand White rabbit was injected with $1 \mathrm{ml}$ of the mixture, divided equally between three sites (two intramuscular, one subcutaneous). A second injection was given intravenously 5 weeks later; this consisted of washed bacteria resuspended in saline to an $\mathrm{OD}_{600}$ of 0.37 . A similar injection was given after a further 1 week, and 4 weeks after that the rabbit was bled. The blood was allowed to clot and the serum removed and frozen at $-20{ }^{\circ} \mathrm{C}$.

Affinity-purified rabbit antiserum. Lyophilized water-extracted haemagglutinin from $R$. salmoninarum Char was rehydrated with water to a concentration of $2 \mathrm{mg} \mathrm{ml}^{-1}$, mixed $1: 1$ with electrophoresis sample buffer and $150 \mu \mathrm{l}$ applied to an SDS-polyacrylamide gel $(10 \% \mathrm{w} / \mathrm{v}$, acrylamide) (minigel). After electrophoresis the gel was electroblotted onto nitrocellulose. The protein bands were located by amido black staining of nitrocellulose strips from both sides of the blot. The nitrocellulose was blocked with $3 \%(\mathrm{w} / \mathrm{v})$ gelatin and then allowed to react with the rabbit antiserum made against whole cells of $R$. salmoninarum ATCC 33209. The amido-black-stained strips were aligned with the blot and the portion containing the haemagglutinin was identified. This strip was excised with a sharp scalpel and cut into small pieces. These were transferred to a test tube and incubated with $1 \mathrm{ml} 100 \mathrm{~mm}$-glycine $(\mathrm{pH} 2.5)$ for $10 \mathrm{~min}$. The buffer was removed, neutralized with $0 \cdot 1$ vol. $1 \mathrm{M}$-Tris $/ \mathrm{HCl}, \mathrm{pH} 8 \cdot 0$, and sodium azide was added to a final concentration of $0.02 \%(\mathrm{w} / \mathrm{v})$.

Indirect fluorescent antibody staining. Rabbit antiserum against whole cells of $R$. salmoninarum was diluted $1 / 100$ with PBS, pH 7.2 (Bacto FA buffer, Difco), and reacted with heat-fixed bacteria on a slide for $30 \mathrm{~min}$. The slides were rinsed in PBS for $10 \mathrm{~min}$ and then reacted with goat anti-rabbit serum labelled with fluorescein isothiocyanate (FITC, Gibco) for $30 \mathrm{~min}$ and rinsed for $10 \mathrm{~min}$ in PBS. Slides were observed with a Zeiss standard microscope, utilizing a IV Fl epi-fluorescent condenser with a high-pressure mercury light source and a standard FITC filter set.

SDS-PAGE. This was performed on $10 \%(\mathrm{w} / \mathrm{v})$ gels with $4 \%(\mathrm{w} / \mathrm{v})$ stacking gels, as described by Laemmli (1970). The proteins were stained with Coomassie brilliant blue R250 and the molecular masses determined by comparison with a set of low molecular mass calibration markers (Pharmacia).

Immunoblot analysis. The water-extracted proteins were subjected to SDS-PAGE ( $10 \%$, w/v resolving gel), as described by Laemmli (1970). After electrophoresis, the proteins were electroblotted from the gel onto nitrocellulose paper $(0.45 \mu \mathrm{m}$, Schleicher and Schuell) using modifications (Burnette, 1981) of the method of Towbin et al. (1979). Immunoblots were developed using alkaline-phosphatase-coupled goat anti-rabbit IgG (Sigma) and $p$-nitroblue tetrazolium chloride and 5-bromo-4-chloro-3-indolyl phosphate $p$-toluidine salt for colour development.
Enzyme treatment. Two milligrams of lyophilized water-extracted haemagglutinin from $R$. salmoninarum ATCC 33209 were rehydrated with $2 \mathrm{ml}$ buffer ( $40 \mathrm{~mm}$-sodium phosphate, $150 \mathrm{~mm}$-sodium chloride, pH 7.2). Either $2.5 \mathrm{mg}$ proteinase K (Sigma) or $2.5 \mathrm{mg}$ trypsin (Sigma) was added to $0.5 \mathrm{ml}$ aliquots of this solution. A control contained no enzyme. The three mixtures were left at $20^{\circ} \mathrm{C}$ for $1 \mathrm{~h}$ and then tested for agglutination of rabbit erythrocytes or rainbow trout spermatozoa. The mixtures were also examined by SDS-PAGE to determine whether the $57 \mathrm{kDa}$ protein was degraded.

Reassembly of haemagglutinin onto $R$. salmoninarum. Cells of $R$. salmoninarum ATCC 33209 were grown for 2 weeks, then washed twice with saline and three times with distilled water until they did not haemagglutinate rabbit erythrocytes or rainbow trout spermatozoa. The optical density of the bacteria was adjusted such that a $1 / 100$ dilution had an $\mathrm{OD}_{520}$ of $0 \cdot 075$. Three milligrams of lyophilized, waterextracted haemagglutinin was rehydrated with $1 \mathrm{ml}$ distilled water and $0.5 \mathrm{ml}$ of this was mixed with $1 \mathrm{ml}$ of washed bacteria and placed in a sterile dialysis membrane sac with a molecular mass exclusion of $10000-12000 \mathrm{Da}$ (Spectrum Medical Industries). The control dialysis sac contained bacteria and no added haemagglutinin. The sacs were dialysed overnight at $4{ }^{\circ} \mathrm{C}$ against saline. After dialysis, the cells were collected, washed three times with saline and reacted with rabbit erythrocytes. The hydrophobicity of both bacterial suspensions was measured by the salt aggregation test.

\section{Results}

\section{Hydrophobic and agglutinating activities of R. salmoninarum}

Nine of the ten strains of $R$. salmoninarum were hydrophobic and readily agglutinated rabbit erythrocytes and rainbow trout spermatozoa. In contrast, strain MT239 was not hydrophobic, giving a SAT value of greater than $2 \cdot 0$, and it also failed to agglutinate rabbit erythrocytes and rainbow trout spermatozoa.

\section{SDS-PAGE profiles of water-extracts}

When the water-extraction procedure for removal of the haemagglutinin of $R$. salmoninarum was employed with strain MT239, no solid material was detected after lyophilization. Using similar amounts of the other strains, milligram amounts of material were extracted. The water-extracted haemagglutinins from these nine strains were compared by SDS-PAGE (Fig. 1a,b). The protein profiles of eight strains, including the type strain (ATCC 33209), were very similar, showing a major protein of $57 \mathrm{kDa}$ with a minor protein of $58 \mathrm{kDa}$. Other proteins of lower molecular mass were also evident. In contrast, the Char strain had a protein of similar intensity to the $57 \mathrm{kDa}$ protein but did not have a $58 \mathrm{kDa}$ protein (Fig. 1b, lane 6). 


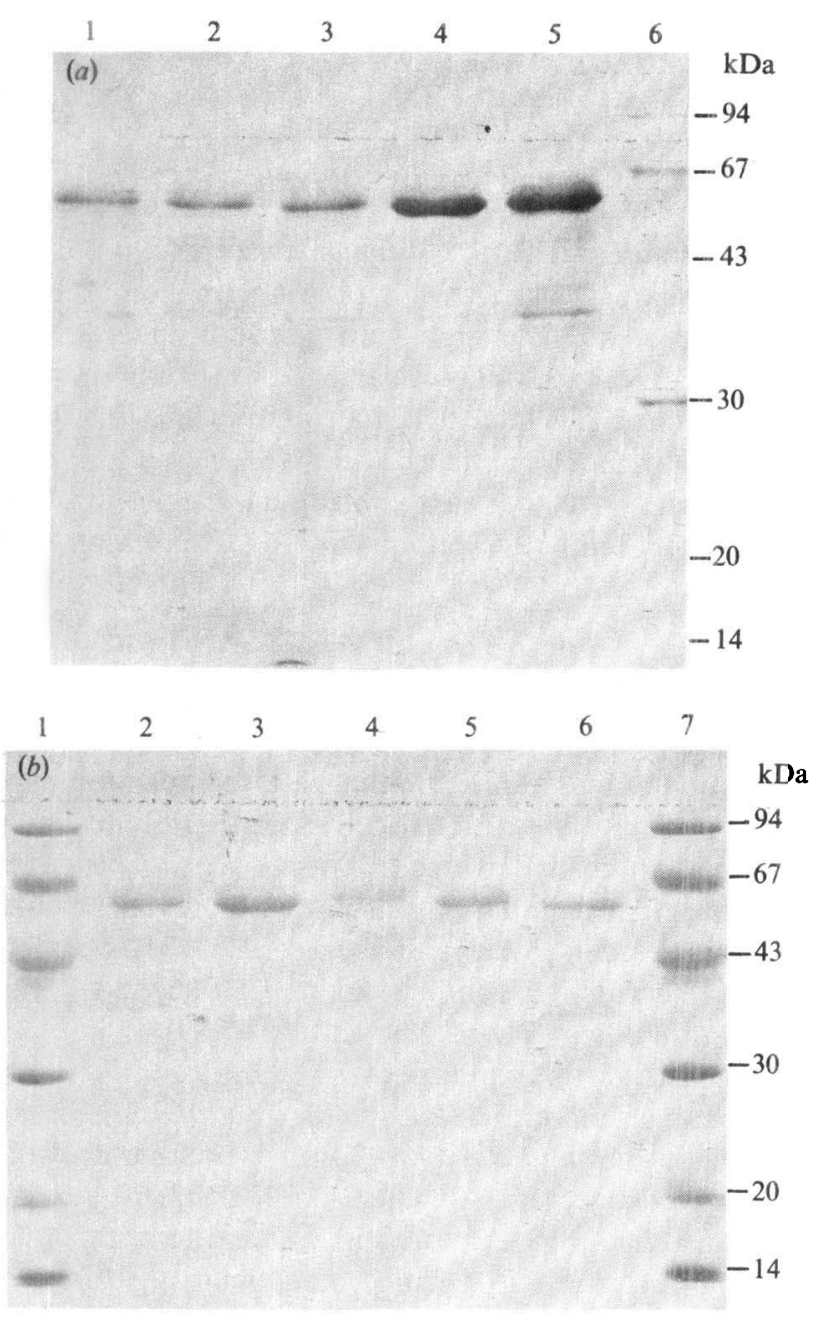

Fig. I. SDS-PAGE ( $10 \%$ acrylamide) of water-extracted proteins from various $R$. salmoninarum strains. (a) Lanes: $1,2 / 2 / 79 ; 2, \mathrm{RS} 22 ; 3$, MT241; 4, NCMB 1111; 5, ATCC 33209; 6, molecular mass standards. (b) Lanes: 1, 7, molecular mass standards; 2, ATCC 33209; 3, Coho (Ontario); 4, NCMB 1114; 5, ATCC 33739; 6, Char. The Pharmacia kit standards are phosphorylase $b(94 \mathrm{kDa})$, bovine serum albumin $(67 \mathrm{kDa})$, ovalbumin $(43 \mathrm{kDa})$, carbonic anhydrase (30 kDa), soybean inhibitor $(20 \mathrm{kDa})$ and $\alpha$-lactalbumin $(14 \mathrm{kDa})$.

\section{Haemagglutinin purification and characterization}

The haemagglutinating proteins from ATCC 33209 and the Char strain were chosen for further purification because of their slightly different profiles on SDSPAGE: After zone electrophoresis in a $5 \%$ nondenaturing gel, the water-extracted haemagglutinin from both strains showed a single intense band upon Coomassie blue staining. After being excised and subjected to SDS-PAGE, the proteins from the two strains were found to have slightly different molecular masses (Fig. $2 a, b)$. The haemagglutinin of the type strain, ATCC 33209, consisted of a doublet, with bands of molecular masses of 57 and $58 \mathrm{kDa}$ (Fig. $2 a$ ). In some

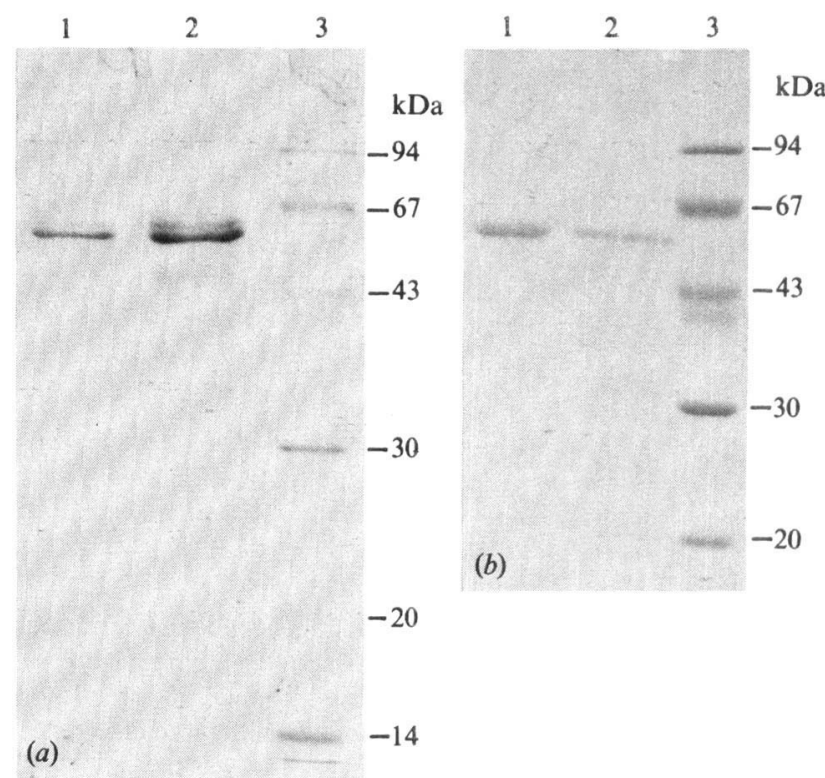

Fig. 2. SDS-PAGE ( $10 \%$ acrylamide) of zone electrophoresis purified haemagglutinins from $R$. salmoninarum ATCC 33209 and Char. (a) Lanes: 1, haemagglutinin purified from ATCC 33209 ; 2, waterextracted proteins from ATCC $33209 ; 3$, molecular mass standards, as in Fig. 1. (b) Lanes: 1, haemagglutinin purified from Char; 2, waterextracted proteins from Char; 3 , molecular mass standards.

preparations, the $58 \mathrm{kDa}$ protein was less evident. The haemagglutinin of the Char strain consisted of a single band of molecular mass $57 \mathrm{kDa}$ (Fig. 2b). The protein from either ATCC 33209 or Char agglutinated both rabbit erythrocytes and rainbow trout spermatozoa, thus demonstrating that the same protein was responsible for both activities.

The $57-58 \mathrm{kDa}$ bands of $R$. salmoninarum ATCC 33209 were degraded by both protease $\mathrm{K}$ and trypsin (Fig. 3); this enzyme treatment also destroyed both haemagglutinating and spermagglutinating activities. The SDS-PAGE profile of the water-extracted proteins was identical if $\beta$-mercaptoethanol was omitted from the electrophoresis sample buffer (Fig. 3), indicating that subunits are not held together by disulphide bridges.

\section{Immunoblot reactions and immunofluorescence microscopy}

In immunoblots of the water-extracted proteins separated by SDS-PAGE, numerous proteins, including the haemagglutinin, reacted with the antiserum produced against whole cells of $R$. salmoninarum ATCC 33209 (Fig. $4 a, b$ ). The Char strain, which did not produce the $58 \mathrm{kDa}$ protein, was used to affinity-purify antibody towards the haemagglutinin from the whole-cell antiserum. When whole-cell antiserum was used as the first antibody for indirect fluorescent antibody staining, cells 


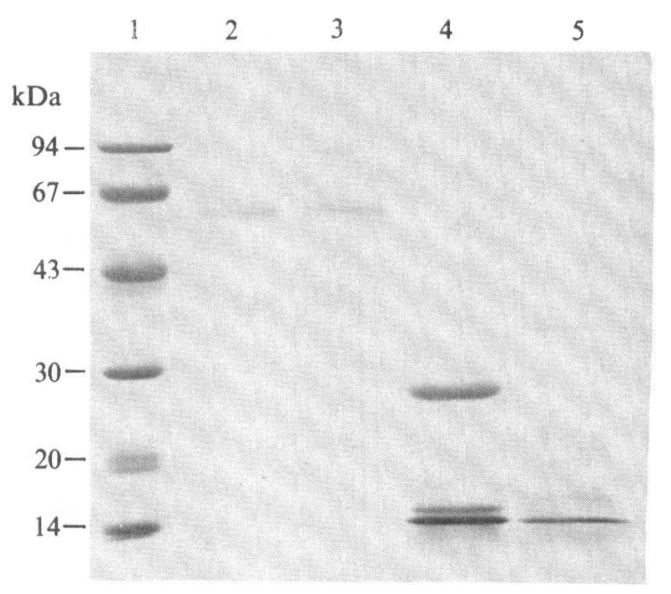

Fig. 3. $\beta$-Mercaptoethanol and enzyme treatment of water-extracted proteins from $R$. salmoninarum ATCC 33209. Lanes: 1 , molecular mass standards; 2 , untreated sample; 3 , untreated sample but without $\beta$ mercaptoethanol in the sample buffer; 4 , treated with proteinase $K ; 5$, treated with trypsin.
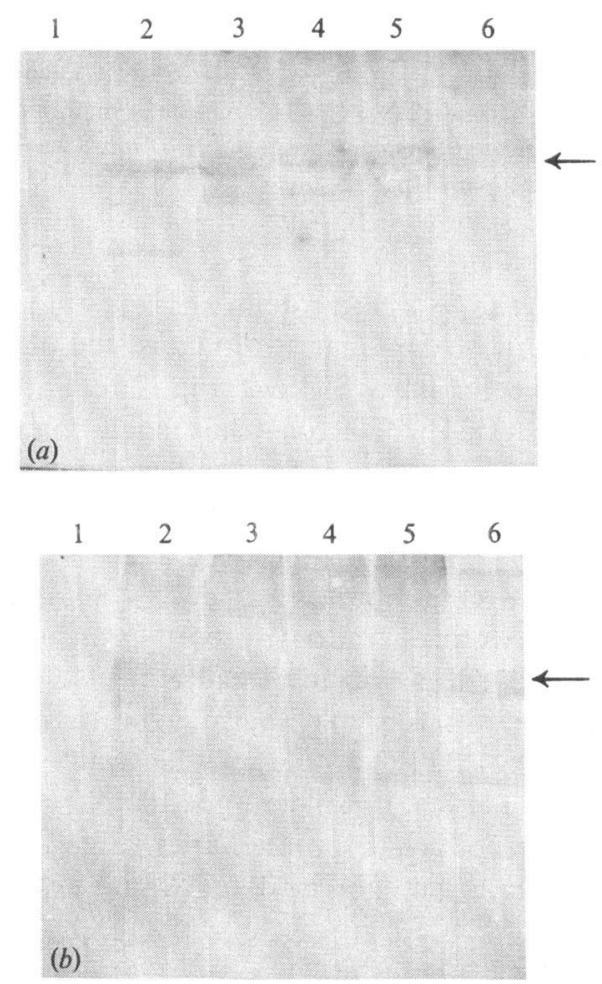

Fig. 4. Western immunoblot of the water-extracted proteins from $R$. salmoninarum isolates, using rabbit antiserum raised against whole cells of $R$. salmoninarum ATCC 33209. (a) Lanes: 1, unstained molecular mass standards; 2, Char; 3, ATCC 33739; 4, NCMB 1114; 5, Coho (Ontario); 6, ATCC 33209. (b) Lanes: 1, unstained molecular mass standards; 2, 2/2/79; 3, RS22; 4, MT241; 5, NCMB 1111; 6, ATCC 33209 . The arrows indicate the position of haemagglutinin.

of ATCC 33209 and MT239 both fluoresced, but when the affinity-purified rabbit anti-haemagglutinin serum was used, only ATCC 33209 fluoresced. This further suggested that MT239 did not produce the haemagglutinin on its surface.

\section{Re-assembly of haemagglutinin onto cells}

Water-extracted cells of $R$. salmoninarum ATCC 33209 dialysed against saline in the presence of homologous water-extracted haemagglutinin readily agglutinated rabbit erythrocytes. These bacteria were much more hydrophobic (SAT value 0.3 ) than control cells that were incubated without haemagglutinin (SAT value $>2 \cdot 0$ ). The bacteria with the reassembled haemagglutinin also auto-aggregated, as observed by phase-contrast microscopy.

\section{Discussion}

The similar SDS-PAGE protein patterns and immunoblots of the water-extracted cell surface proteins show that geographically diverse strains of $R$. salmoninarum are serologically similar, consistent with previous results using whole-cell serology (Bullock et al., 1974), counterimmunoelectrophoresis (Getchell et al., 1985) and monoclonal antibodies (Weins \& Kaattari, 1989).

The basis for this similarity is the $57 \mathrm{kDa}$ antigen that was found in all strains except MT239, which did not have agglutinating activity and from which no material was water-extracted. All agglutinating strains, except Char, also had a $58 \mathrm{kDa}$ protein. When the haemagglutinating activity was purified, the haemagglutinin of ATCC 33209 consisted of a doublet containing both the 57 and $58 \mathrm{kDa}$ proteins, whereas the Char haemagglutinin contained only the $57 \mathrm{kDa}$ protein. Thus, only the $57 \mathrm{kDa}$ protein is necessary for the haemagglutinating activity for the Char strain, whereas haemagglutinating activity may be associated with both the 57 and $58 \mathrm{kDa}$ proteins of the other strains. The partially purified antigen $F$ described by Getchell et al. (1985) has a major band of $57 \mathrm{kDa}$, thus the haemagglutinin is presumably antigen F. Recently, Weins \& Kaattari (1989) described monoclonal antibodies that react with both the 57 and $58 \mathrm{kDa}$ proteins, indicating that they are antigenically related. Presumably the proteins of lower molecular mass than the 57 and $58 \mathrm{kDa}$ doublet are breakdown products of the haemagglutinin. Weins \& Kaattari (1989) also demonstrated that both the 57 and $58 \mathrm{kDa}$ proteins were present in the sera of fish infected with bacterial kidney disease, but the lower molecular mass proteins were not evident.

The non-hydrophobic (hydrophilic) nature of $R$. salmoninarum MT239 was previously reported by Bruno (1988). In this study, we were unable to extract haemagglutinin from the surface of this strain, to detect 
haemagglutinating or spermagglutinating activity, or to observe staining of MT239 cells using affinity-purified antibody to the haemagglutinin and fluorescence microscopy. Previously we showed that the water-extracted haemagglutinin was hydrophobic (Daly \& Stevenson, 1987); hence the lack of the haemagglutinin on the surface of MT239 may be responsible for making its cell surface less hydrophobic.

The hydrophobic nature of the haemagglutinin (Daly \& Stevenson, 1987) would account for the observation that the haemagglutinin reassembled onto the bacterial surface. Previously, we had found that protease enzymes had little or no effect on the haemagglutinating activity of whole bacteria (Daly \& Stevenson, 1987). As these enzymes are able to degrade the water-extracted haemagglutinin (Fig. 3), this suggests that in its native form, it must be folded in such a way that the sites that are labile to trypsin and proteinase $\mathrm{K}$ are hidden.

The present results demonstrate that $F$ antigen or soluble antigen, haemagglutinin and spermagglutinin are all the same molecule, usually seen as a 57 and $58 \mathrm{kDa}$ doublet protein on SDS-PAGE. It is important to clarify and summarize the literature in regard to this important antigen of $R$. salmoninarum. This hydrophobic protein, designated antigen $\mathrm{F}$ as one of seven antigens described by Getchell et al. (1985), is found both on the cell surface and in broth supernatant fluid of cultured cells (Getchell et al., 1985; Daly \& Stevenson, 1987). It agglutinates rabbit erythrocytes and salmonid spermatozoa (Daly \& Stevenson, 1987, 1989). Antigen F can self-assemble onto the renibacterial cell surface, with which it is loosely associated, and it can be extracted by distilled water or heat (this report; Daly \& Stevenson, 1987). This latter property and the heat stability of the protein have been used to detect antigen $\mathrm{F}$ and $R$. salmoninarum in infected fish by ELISA (Pascho \& Mulcahy, 1987) and coagglutination (Kimura \& Yoshimizu, 1981).

The function of $F$ antigen in the disease process is unknown, although its hydrophobic nature may allow the bacteria to bind to specific tissues and gain entrance to salmonid ova (Daly \& Stevenson, 1987). Bruno (1988) found that the non-hydrophobic strain MT239 was less virulent than hydrophobic strains of $R$. salmoninarum. As our study has shown that MT239 lacks the F antigen, it may be an important virulence factor. Turaga et al. (1987) found that soluble antigens, containing the $F$ antigen, suppressed in vitro antibody responses of coho salmon lymphocytes; perhaps $\mathrm{F}$ antigen is responsible for this effect.

The Ontario Ministry of Natural Resources provided financial support for this study. J. G. D. gratefully acknowledges a postgraduate scholarship from the Natural Sciences and Engineering Research Council of Canada.

\section{References}

BRUNo, D. W. (1988). The relationship between auto-aggregation, cell surface hydrophobicity and virulence of the fish pathogen Renibacterium salmoninarum. FEMS Microbiology Letters 51, 135-140.

Bullock, G. L., Stuckey, H. W. \& Chen, P. K. (1974). Corynebacterial kidney disease of salmonids: growth and serological studies on the causative bacterium. Applied Microbiology 28, 811-814.

BURNETTE, W. N. (1981). 'Western blotting': electrophoretic transfer of proteins from sodium dodecyl sulfate-polyacrylamide gels to unmodified nitrocellulose and radiographic detection with antibody and radioiodinated protein A. Analytical Biochemistry 112, 195-203.

Daly, J. G. \& Stevenson, R. M. W. (1985). Charcoal agar, a new growth medium for the fish disease bacterium Renibacterium salmoninarum. Applied and Environmental Microbiology 50, 868-871.

Daly, J. G. \& Stevenson, R. M. W. (1987). Hydrophobic and haemagglutinating properties of Renibacterium salmoninarum. Journal of General Microbiology 133, 3575-3580.

Daly, J. G. \& Stevenson, R. M. W. (1989). Agglutination of salmonid spermatozoa by Renibacterium salmoninarum. Journal of Aquatic Animal Health 1, 163-164.

FRYER, J. L. \& SANDERS, J. E. (1981). Bacterial kidney disease of salmonid fish. Annual Review of Microbiology 35, 273-298.

Getchell, R. G., Rohovec, J. S. \& Fryer, J. L. (1985). Comparison of Renibacterium salmoninarum isolates by antigenic analysis. Fish Pathology 20, 149-159.

Kimura, T. \& YoshimizU, M. (1981). A coagglutination test with antibody sensitized staphylococci for rapid and simple diagnosis of bacterial kidney disease (BKD). Developments in Biological Standardization 49, 135-148.

LAEMmLi, U. K. (1970). Cleavage of structural proteins during the assembly of the head of the bacteriophage T4. Nature, London 227, 680-685.

PaSCHO, R. J. \& MulcaHY, D. (1987). Enzyme-linked immunosorbent assay for a soluble antigen of Renibacterium salmoninarum, the causative agent of salmonid bacterial kidney disease. Canadian Journal of Fisheries and Aquatic Sciences 44, 183-191.

SANDERS, J. E. \& FRYER, J. L. (1980). Renibacterium salmoninarum gen. nov., sp. nov., the causative agent of bacterial kidney disease in salmonid fishes. International Journal of Systematic Bacteriology 30, 496-502.

Towbin, M., Staehelin, T. \& Gordon, J. (1979). Electrophoretic transfer of proteins from polyacrylamide gels to nitrocellulose sheets: procedure and some applications. Proceedings of the National Academy of Sciences of the United States of America 76, 4350-4354.

Turaga, P., Weins, G. \& KaAtTari, S. (1987). Bacterial kidney disease: the potential role of soluble protein antigen(s). Journal of Fish Biology 31 (supplement A), 191-194.

WeINS, G. D. \& KaAtTARI, S. L. (1989). Monoclonal antibody analysis of common surface protein(s) of Renibacterium salmoninarum. Fish Pathology 24, 1-7. 